\title{
Determinan Tingkat Partisipasi Zakat Di Masa Pandemi Covid-19
}

\author{
Hamni Fadlilah Nasution', Zulaika Matondang², Rodame Monitorir Napitupulu3 \\ 1,2,3 Institut Agama Islam Negeri Padangsidimpuan \\ 1,2,3 Jl. H.T. Rizal Nurdin Km 4,5 Sihitang Kota Padangsidimpuan \\ E-mail: zulaikamatondang83@gmail.com ${ }^{1}$, hamnifadlilahnasution@gmail.com², \\ napitupulurm@gmail.com ${ }^{3}$
}

\begin{abstract}
Abstrak
Keterpurukan perekonomian di masa pandemic menyebabkan angka kemiskinan meningkat. Salah satu cara mengatasi kemiskinan dalam ajaran Islam adalah berzakat. Dosen dan pegawai di IAIN Padangsidimpuan yang memiliki penghasilan tetap bisa menjadi muzakki untuk membantu mustahiq keluar dari keterpurukannya. Penelitian ini bertujuan untuk menganalisis determinan tingkat partisipasi berzakat dosen dan pegawai IAIN Padangsidimpuan di masa pandemic covid-19. Metode yang digunakan dalam penelitian ini adalah analisis regresi dengan jenis penelitian kuantitatif dengan data primer. Hasil penelitian ini menunjukkan bahwa faktor keimanan dan factor kepuasan diri dapat memengaruhi tingkat partisipasi berzakat, sedangkan faktor penghargaan, altruism dan organisasi tidak memengaruhi tingkat partisipasi berzakat.
\end{abstract}

\section{Kata Kunci : Zakat, Partisipasi, Covid-19}

\begin{abstract}
Economic downturn during the pandemic era has caused the poverty rate to increase. One of manners to overcome poverty in Islamic gospel is to give zakah or tithe. The lecturers and employees at IAIN Padangsidimpuan who have permanent stages can become muzakki to help mustahiq get out of their economic downturn. This study aims to analyze the level of zakah participation of lecturers and staff of IAIN Padangsidimpuan during the COVID-19 pandemic. The method used in this research is regression analysis in quantitative research design with primary data. The results showed that the faith and self-satisfaction factors can affect the level of zakah participation, while the appreciation, altruism and organization factor do not affect the level of zakah participation.
\end{abstract}

Keywords: Zakah, Participation, COVID-19 


\section{PENDAHULUAN}

Awal maret 2020, pemerintah pertama kali mengumumkan adanya kasus pandemic covid-19 di Indonesia. Sampai akhir juli 2020 jumlah orang yang terinfeksi virus corona-19 di Indonesia mencapai kurang lebih seratus ribuan orang. Hal ini sangat berdampak pada perekonomian masyarakat, perekonomian Indonesia dan bahkan perekonomian dunia. Hanya dalam beberapa bulan saja, tatanan ekonomi berubah total, sampai-sampai di Indonesia masalah ini menjadi darurat bencana nasional. Keadaan ini, banyak memaksa perusahaan untuk mengurangi jumlah produksi akibat pemasok yang tidak lagi beroperasi dan harga produksi yang perlahan-lahan mengalami peningkatan, demi mempertahankan perusahaan, dilakukan pengurangan jumlah karyawan, sehingga banyaklah para karyawan yang dirumahkan. Karyawan yang dirumahkan menambah deretan pengangguran di masa pandemi covid, sehingga angka kemiskinan tak dapat lagi dielakkan peningkatannya.

Kemiskinan salah satu masalah dalam perekonomian suatu wilayah menurut ilmu ekonomi makro. Kemiskinan dapat terjadi akibat kehilangan pekerjaan, sehingga mengakibatkan ketidakmampuan dalam memenuhi makanan, pakaian dan bahkan tempat tinggal, sehingga akses pendidikan dan kesehatan menjadi rendah. Keadaan pandemic covid sekarang ini, mengakibatkan banyaknya perusahaan yang merumahkan karyawannya, sehingga angka pengangguran mengalami peningkatan. Selain itu, banyak tempat-tempat usaha yang tutup, sekolah dan kampus diliburkan, sehingga aktifitas disekitar kampus yang juga merupakan ladang usaha buat sebahagian masyarakat menjadi terhenti. Sehingga banyak masyarakat yang mengalami kekurangan dalam hal makanan, pakaian dan bahkan tempat tinggal. Kesulitan-kesulitan ini bukan hanya dirasakan di kota-kota yang berada pada zona merah, akan tetapi dirasakan di semua wilayah di Indonesia, tidak terkecuali di kota Padangsidimpuan. Kota Padangsidimpuan masuk ke dalam zona kuning dengan jumlah kasus masih dibawah 10 kasus covid-19. Kota padangsidimpuan memiliki luas wilayah 146,85 km² yang berada di tengah-tengah kabupaten Tapanuli Selatan, sebelah utara berbatasan dengan wilayah Kabupaten Tapanuli Selatan yaitu kecamatan angkola timur, sebelah selatan berbatasan dengan wilayah Kabupaten Tapanuli Selatan yaitu kecamatan Batang Angkola dan kecamatan Angkola Selatan, sebelah barat berbatasan dengan wilayah Kabupaten Tapanuli Selatan yaitu kecamatan Angkola Barat dan kecamatan Angkola Selatan, dan sebelah timur berbatasan dengan wilayah Kabupaten Tapanuli Selatan yaitu kecamatan Angkola Timur.

Pandemic covid-19 sudah merubah banyak tatanan kehidupan dan kondisi perekonomian dan keuangan masyarakat, bukan hanya masyarakat yang berpenghasilan tetap setiap bulannya akan tetapi lebih dirasakan lagi oleh masyarakat yang berpenghasilan tidak 
tetap. Sejak akhir bulan maret tahun 2020, baik kantor pemerintahan dan juga perusahaan swasta dialihkan pekerjaan menjadi work from home, begitu juga yang terjadi di IAIN Padangsidimpuan. Bank Indonesia kantor perwakilan Sumatera Utara yang disampaikan kepala perwakilan bapak Wiwiek Sisto Hidayat memperkirakan terjadi peningkatan angka kemiskinan mencapai 1,8 juta jiwa sebagai dampak pandemi covid-19, pertambahan tingkat kemiskinan sebagai dampak pelemahan ekonomi dan tingkat kemiskinan mengalami peningkatan menjadi 9,7 persen pada scenario mild dan dalam scenario severe meningkat hingga 12,9 persen. Dampak covid-19 juga akan berdampak pada ketenagakerjaan dengan banyaknya lapangan usaha yang tutup, dan ada empat sector utama yang rentan memPHK-kan pekerjanya atau sekitar 354 ribu tenaga kerja yang akan terdampak (WASPADA, 2020).

IAIN Padangsidimpuan adalah salah satu institusi pemerintah yang memiliki ... orang pegawai, dimasa pandemic covid-19 para pegawai yang memiliki penghasilan tetap juga merasakan dampaknya seperti yang dirasakan oleh para pegawai di lingkungan IAIN Padangsidimpuan, dimana kebutuhan hidup yang melonjak naik sedangkan penghasilan yang tidak mengalami peningkatan. Walau dalam kondisi seperti itu, IAIN Padangsidimpuan ikut berpartisipasi membantu pemerintah dalam mengatasi kesulitan yang dirasakan masyarakat di masa pandemic covid-19 dengan menyumbangkan sebahagian dari penghasilannya yang dikumpulkan secara kumulatif dan digunakan untuk membantu masyarakat sekitar dalam pemenuhan kebutuhan hidup.

Islam adalah agama yang rahmatan lil'alamin untuk semua makhluk. Kemiskinan dalam Islam bukanlah masalah, Islam memberikan solusi dalam pengentasan kemiskinan dalam bentuk zakat, karena menurut Qardhawi, Islam tidak menempatkan masalah zakat sebagai urusan pribadi, tetapi sebagai salah satu tugas pemerintahan Islam, dalam hubungan ini Islam menyerahkan wewenang kepada negara untuk memungut dan membagikannya kepada yang berhak (Setiawan \& Hasanah, 2016). Masa pandemic covid-19 terjadi peningkatan jumlah muslim yang hidup dalam kemiskinan. Dimana kemiskinan tumbuh lebih cepat daripada peningkatan jumlah pembayar zakat yang mencerminkan kepatuhan terhadap Al-Qur'an dan Hadist yang rendah dalam membayar zakat dikalangan muslim (Salwa dkk., 2018). Kepatuhan dan partisipasi seorang individu untuk berzakat ini didasari atas keimanan yang dimiliki oleh individunya, selain keimanan factor altruism (kepekaan social) juga menjadi factor suatu individu dalam mengeluarkan zakat. Anjuran tiap individu yang mampu untuk berzakat terdapat dalam Al-Qur'an surah Al-Baqarah ayat 43 yang artinya "Dirikanlah shalat dan berikanlah zakat, dan ruku'lah bersama-sama orang yang ruku”. Berdasarkan latar belakang tersebut, penelitian ini bertujuan untuk menganalisis determinan tingkat partisipasi berzakat di 
masa pandemic covid-19 untuk mengetahui tingkat keimanan, penghargaan, altruism, organisasi dan kepuasan diri.

\section{KAJIAN TEORITIS}

Zakat digunakan sebagai alat untuk membersihkan harta, zakat dapat berupa zakat profesi, zakat mal dan ada juga istilah zakat nafs. Zakat profesi dikeluarkan bagi individu yang memperoleh penghasilan dari pekerjaannya dan nilai penghasilan tersebut sudah melebihi nisab dalam setahun. Menurut Yusuf al-Qardawi, zakat profesi harus memenuhi syarat hawl (harta cukup satu tahun) dan diqiyaskan dengan emas atau zakat perdagangan 2,5 persen senilai 85 gram emas murni (Hadi, 2010).

Zakat termasuk sedekah, bedanya kalau zakat hukumnya wajib sementara sedekah hukumnya sunnah. Nabi menjelaskan bahwa sedekah akan membuahkan tiga hal, yaitu bisa memadamkan kemurkaan Allah, bisa menyebabkan rizki menjadi barokah dan bisa menarik rizki yang banyak (Nakhrawie, 2011). Anjuran bagi umat Islam untuk berzakat dilatarbelakangi oleh beberapa factor, seperti penelitian yang dilakukan oleh (Beik \& Alhasanah, 2012) tentang analisis factor-faktor yang mempengaruhi tingkat partisipasi dan pemilihan tempat berzakat dan berinfak, yang menjelaskan bahwa factor yang memengaruhi partisipasi berzakat adalah factor keimanan, factor altruism (kepekaan social), factor penghargaan, factor organisasi dan factor pendapatan, dan factor yang memengaruhi partisipasi rutin berinfak adalah factor keimanan, factor altruism, factor kepuasan, factor Pendidikan dan frekuensi infak. Sedangkan factor yang memengaruhi pemilihan tempat membayar zakat adalah factor Pendidikan dan keberadaan Organisasi Pengelola Zakat (OPZ).

\section{Pengaruh Keimanan dan altruism terhadap tingkat partisipasi berzakat}

Iman artinya percaya, yaitu membenarkan dan meyakinkan dengan hati, diucapkan oleh lisan dan diamalkan dengan perbuatan, iman akan mendorong seseorang untuk melakukan suruhan Allah dan Rasulullah dan meninggalkan segala larangannya. Hubungan iman dengan zakat sangat erat, karena zakat adalah suruhan Allah dan merupakan rukun Islam yang ke empat, (Azzahra \& Majid, 2020) berpendapat bahwa iman, altruism, kualitas layanan, peran ekonomi zakat dan peran ulama dapat memengaruhi keputusan muzakki untuk membayar zakat.

Tingkat partisipasi berzakat salah satunya dipengaruhi oleh factor keimanan, dimana kerelaan seorang muslim untuk mengeluarkan sebahagian hartanya dalam bentuk zakat didasari atas kepatuhan terhadap Al-Qur'an dan Hadist. (Al Jaffri Saad \& Haniffa, 2014) melakukan pengujian determinants of zakah (Islamic tax) compliance behavior untuk JISFIM: Journal of Islamic Social Finance Management, Volume 1, No 2 Tahun 2020 http://jurnal.iain-padangsidimpuan.ac.id/index.php/JISFIM 
menyelidiki apakah sikap, norma subyektif dan niat adalah penentu perilaku kepatuhan zakat, dan hasilnya menjelaskan bahwa niat menjadi predictor untuk perilaku kepatuhan zakat, dan niat dipengaruhi oleh sikap dan norma subyektif dan menjadi mediasi hubungan sikap dan norma subyektif dengan perilaku kepatuhan berzakat untuk meningkatkan pengumpulan zakat di masa yang akan datang.

\section{Pengaruh organisasi terhadap tingkat partisipasi berzakat}

Selama ini masih banyak umat Islam yang menyerahkan zakatnya secara langsung ke mustahik nya, dan kebanyakan mustahik menggunakan zakat yang diperoleh untuk kebutuhan konsumtif. Padahal, tujuan zakat adalah untuk membantu masyarakat yang kurang mampu dan sebagai solusi dalam mengentaskan kemiskinan. Jika zakat yang diberikan hanya bersifat konsumtif, maka zakat tersebut belum mampu membantu masyarakat miskin untuk lepas dari keterpurukan. Agar zakat menjadi bermanfaat, perlu dikelola oleh organisasi atau Lembaga pengumpul zakat. Lembaga pengumpul zakat yang kita kenal dengan BAZNAS untuk tingkat nasional dan BAZDA untuk tingkat daerah sudah Menyusun dan melaksanakan kebijakan pengelolaan zakat produktif sebagai upaya untuk membantu masyarakat yang kurang mampu dengan diberikan modal usaha dan pelatihan serta terus didampingi agar zakat yang digunakan bermanfaat. Hal ini dapat berjalan dengan baik jika ada Kerjasama antara pemerintah sebagai pengelola zakat dan masyarakat yang bertindak sebagai muzakki. (Cokrohadisumarto dkk., 2019) mengatakan bahwa perilaku masyarakat dalam membayar zakat dapat dibentuk melalui dua hal yaitu dengan meningkatkan pemahaman zakat kepada masyarakat dan memperkuat kredibilitas Lembaga pengelola zakat dengan memberikan informasi yang lengkap kepada masyarakat mengenai keberadaan dan apa yang sudah dilakukan serta apa yang akan dilakukan oleh Lembaga pengelola zakat.

Lembaga zakat juga berperan dalam mengentaskan kemiskinan di suatu negara melalui program-program yang dibuat oleh pemerintah, salah satu Lembaga zakat diindonesia adalah LAZ (Lembaga Amil Zakat) dan BAZNAS (Badan Amil Zakat Nasional). Salah satu program untuk pengentasan kemiskinan yang dilakukanoleh Lembaga zakat adalah pemberdayaan mustahik dibidang ekonomi yang sudah diteliti oleh (Trianto dkk., 2020) tentang apakah demografi dan social budaya mustahik mempengaruhi keberhasilan pengurangan kemiskinan, dengan hasil bahwa anggota rumah tangga dan status pekerjaan dapat memengaruhi keberhasilan dalam menghapus kemiskinan mustahik, sedangkan jenis kelamin, tingkat Pendidikan, usia dan lokasi tempat tinggal, kebiasaan masyarakat dan religiusitas tidak memengaruhi keberhasilan dalam menghapus kemiskinan mustahik. Agar program pemberdayaan mustahik dapat berjalan dengan baik, Lembaga zakat harus memperhatikan 
demografi social-budaya mustahik untuk mendapatkan hasil yang maksimal. Selain itu kelangsungan hidup Lembaga zakat memiliki hubungan langsung dengan tingkat kepercayaan oleh para muzakki dengan memperhatikan tata Kelola public, kualitas distribusi zakat, dan kualitas layanan (Muhammad \& Saad, 2016).

\section{METODE PENELITIAN}

\section{Waktu dan Lokasi Penelitian}

Penelitian ini dilaksanakan pada bulan juni sampai bulan juli tahun 2020. Penelitian ini dilaksanakan di Institut Agama Islam Negeri (IAIN) Padangsidimpuan dengan mencakup biro rector, pasca sarjana, pusat bahasa, empat fakultas yaitu fakultas tarbiyah dan ilmu keguruan, fakultas Syariah dan ilmu hukum, fakultas dakwah dan ilmu komunikasi, serta fakultas ekonomi dan bisnis Islam, lembaga penjaminan mutu, Lembaga penelitian dan pengabdian masyarakat dan perpustakaan.

\section{Jenis dan sumber data}

Penelitian ini dilakukan dengan metode penelitian kuantitatif, yaitu metode yang digunakan untuk menguji teori-teori tertentu dengan cara meneliti hubungan antarvariabel yang menghasilkan data-data dalam bentuk angka-angka sehingga dapat dianalisis berdasarkan prosedur statistik (Noor, 2015). Penelitian ini menggunakan data primer, dimana data primer ini diambil dengan menggunakan kuesioner melalui google form. Dan data sekunder yang diperoleh dari dokumen-dokumen baik yang dipublikasi maupun yang tidak dipublikasi yang terkait dengan tema penelitian ini.

\section{Populasi dan Sampel}

Sejak awal perlu melakukan identifikasi populasi secara tepat dan akurat, jika populasi tidak diketahui dengan jelas maka kesimpulan yang dihasilkan bisa saja keliru. Populasi terdiri dari obyek atau subyek yang mempunyai kuantitas dan karakteristik tertentu, jadi populasi bukan hanya orang, tetapi juga obyek dan benda lainnya, bukan sekedar jumlah yang ada pada obyek/subyek yang dipelajari tetapi meliputi seluruh karakteristik/sifat yang dimiliki oleh subyek atau obyek yang diteliti itu (Sugiyono, 2017). Sehingga populasi dalam penelitian ini adalah seluruh pegawai civitas akademika IAIN Padangsidimpuan sebanyak 285 Orang. Sampel merupakan bagian dari populasi yang mencakup sejumlah anggota yang dipilih dari populasi. Penarikan sampel dilakukan dengan menggunakan sampling insidental yaitu mengambil sampel secara kebetulan, yaitu siapa saja yang secara kebetulan bertemu dengan peneliti dapat digunakan sebagai sampel, bila dipandang orang yang kebetulan ditemui itu cocok sebagai sumber data dan untuk menentukan jumlah sampel digunakan rumus Taro Yamane dan JISHIIVI: Journal of ISIamic social Finance Ivianagement, volume 1, No 2 I anun 2020 http://jurnal.iain-padangsidimpuan.ac.id/index.php/JISFIM 
berdasarkan perhitungan tersebut, batas sampel minimum dalam penelitian ini sebanyak 75 orang, sedangkan jumlah sampel dalam penelitian ini sebanyak 84 orang dosen dan pegawai di lingkungan IAIN Padangsidimpuan

\section{Teknik Analisa Data}

Sebelum masuk pada pengolahan data, angket yang dibagikan melalui google form dikumpulkan hingga mencapai jumlah sampel yang sudah ditentukan. Setelah data diperoleh, berikutnya dilakukan pengolahan data dengan menggunakan SPSS (Statistical Product and Service Solution ) versi 23. Teknik analisis data dalam penelitian ini menggunakan analisis regresi linier berganda, Pengujian terhadap data dimulai dari uji validitas dan uji reliabilitas, uji normalitas, uji linieritas, uji asumsi klasik dan uji hipotesis.

\section{HASIL DAN PEMBAHASAN}

\section{Deskripsi Responden}

Responden yang menjadi sampel dalam penelitian ini sebanyak 84 orang. Berdasarkan kuesioner yang telah disebarkan kepada responden dapat dilakukan pengidentifikasian responden berdasarkan karakteristik jenis kelamin, usia pada saat mengisi kuesioner, tingkat Pendidikan, pekerjaan saat mengisi kuesioner, lama bekerja di IAIN Padangsidimpuan dan pendapatan per bulannya. Rincian tersebut dapat di deskripsikan pada tabel berikut.

Tabel 1

Karakteristik Responden

\begin{tabular}{cccc}
\hline Karakteristik & Responden & Jumlah & Persentase \\
\hline \multirow{2}{*}{ Jenis Kelamin } & Laki-laki & 39 & 46,4 \\
& Perempuan & 45 & 53,6 \\
Usia & $25-30$ Tahun & 24 & 28,6 \\
& $31-35$ Tahun & 26 & 31 \\
& 36-40 Tahun & 23 & 27,4 \\
& $41-50$ Tahun & 11 & 13,1 \\
Tingkat Pendidikan & D3 & 1 & 1,2 \\
& S1 & 25 & 29,8 \\
& S2 & 51 & 60,7 \\
Pekerjaan & S3 & 7 & 8,3 \\
& Dosen & 58 & 69 \\
& Pegawai & 26 & 31
\end{tabular}

JISFIM: Journal of Islamic Social Finance Management, Volume 1, No 2 Tahun 2020 http://jurnal.iain-padangsidimpuan.ac.id/index.php/JISFIM 
238 I Determinan Tingkat Partisipasi Zakat Di Masa Pandemi Covid -19

$\begin{array}{cccc} & \text { 1-5 Tahun } & 39 & 46,4 \\ \text { 6-10 Tahun } & 29 & 34,5 \\ \text { Lama bekerja } & \text { 11-15 Tahun } & 4 & 4,8 \\ & \text { 16-20 Tahun } & 4 & 4,8 \\ & >20 \text { Tahun } & 2 & 2,4 \\ \text { Pendapatan/bulan } & <\text { juta rupiah } & 30 & 35,7 \\ & 2-5 \text { juta rupiah } & 36 & 42,9 \\ & >5 \text { juta rupiah } & 18 & 21,4\end{array}$

Sumber : data diolah

\section{Deskripsi Variabel Keimanan}

Variable keimanan diukur dengan skala ordinal dengan jumlah pernyataan sebanyak 4 item, dan persentase jawaban responden atas pernyataan dapat dilihat pada tabel berikut.

Tabel 2

Persentase Jawaban Responden untuk Variabel Keimanan

\begin{tabular}{cccc}
\hline No & Jawaban & Jumlah & Persentase \\
\hline 1 & Sangat Setuju & 55 & 16,4 \\
2 & Setuju & 136 & 40,5 \\
3 & Ragu-Ragu & 116 & 34,5 \\
4 & Tidak Setuju & 29 & 8,6 \\
5 & Sangat Tidak Setuju & 0 & 0 \\
\hline
\end{tabular}

Sumber : Data diolah

\section{Deskripsi Variabel Penghargaan}

Variable Penghargaan diukur dengan skala ordinal dengan jumlah pernyataan sebanyak 4 item, dan persentase jawaban responden atas pernyataan dapat dilihat pada tabel berikut.

Tabel 3

Persentase Jawaban Responden untuk Variabel Penghargaan

\begin{tabular}{cccc}
\hline No & Jawaban & Jumlah & Persentase \\
\hline 1 & Sangat Setuju & 41 & 12,2 \\
2 & Setuju & 145 & 43,2 \\
3 & Ragu-Ragu & 119 & 35,4 \\
4 & Tidak Setuju & 31 & 9,2
\end{tabular}

JISFIM: Journal of Islamic Social Finance Management, Volume 1, No 2 Tahun 2020 http://jurnal.iain-padangsidimpuan.ac.id/index.php/JISFIM 
$\mathrm{O}$

Sumber : Data diolah

\section{Deskripsi Variabel Altruisme}

Variable altruism diukur dengan skala ordinal dengan jumlah pernyataan sebanyak 4 item, dan persentase jawaban responden atas pernyataan dapat dilihat pada tabel berikut.

\section{Tabel 4}

\section{Persentase Jawaban Responden untuk Variabel Altruisme}

\begin{tabular}{cccc}
\hline No & Jawaban & Jumlah & Persentase \\
\hline 1 & Sangat Setuju & 32 & 9,5 \\
2 & Setuju & 148 & 44 \\
3 & Ragu-Ragu & 131 & 39 \\
4 & Tidak Setuju & 25 & 7,4 \\
5 & Sangat Tidak Setuju & o & o \\
\hline
\end{tabular}

Sumber : Data diolah

\section{Deskripsi Variabel Kepuasan Diri}

Variable kepuasan diri diukur dengan skala ordinal dengan jumlah pernyataan sebanyak 4 item, dan persentase jawaban responden atas pernyataan dapat dilihat pada tabel berikut.

Tabel 5

Persentase Jawaban Responden untuk Variabel Kepuasan Diri

\begin{tabular}{cccc}
\hline No & Jawaban & Jumlah & Persentase \\
\hline 1 & Sangat Setuju & 36 & 10,7 \\
2 & Setuju & 147 & 43,8 \\
3 & Ragu-Ragu & 127 & 37,8 \\
4 & Tidak Setuju & 26 & 7,7 \\
5 & Sangat Tidak Setuju & 0 & o \\
\hline
\end{tabular}

Sumber : Data diolah

\section{Deskripsi Variabel Organisasi}

Variable organisasi diukur dengan skala ordinal dengan jumlah pernyataan sebanyak 4 item, dan persentase jawaban responden atas pernyataan dapat dilihat pada tabel berikut.

\section{Tabel 6}

\section{Persentase Jawaban Responden untuk Variabel Organisasi}

\begin{tabular}{cccc}
\hline No & Jawaban & Jumlah & Persentase \\
\hline & JISFIM: Journal of Islamic Social Finance Management, Volume 1, No 2 Tahun 2020 \\
http://jurnal.iain-padangsidimpuan.ac.id/index.php/JISFIM
\end{tabular}


240 I Determinan Tingkat Partisipasi Zakat Di Masa Pandemi Covid-19

\begin{tabular}{lccc}
\hline 1 & Sangat Setuju & 44 & 13,1 \\
2 & Setuju & 145 & 43,2 \\
3 & Ragu-Ragu & 119 & 35,4 \\
4 & Tidak Setuju & 28 & 8,3 \\
5 & Sangat Tidak Setuju & o & o \\
\hline
\end{tabular}

Sumber : Data diolah

\section{Deskripsi Variabel Tingkat Partisipasi Berzakat}

Variable tingkat partisipasi berzakat diukur dengan skala ordinal dengan jumlah pernyataan sebanyak 4 item, dan persentase jawaban responden atas pernyataan dapat dilihat pada tabel berikut.

Tabel 7

Persentase Jawaban Responden untuk Variabel Tingkat Partisipasi Berzakat

\begin{tabular}{cccc}
\hline No & Jawaban & Jumlah & Persentase \\
\hline 1 & Sangat Setuju & 43 & 12,8 \\
2 & Setuju & 145 & 43,2 \\
3 & Ragu-Ragu & 119 & 35,4 \\
4 & Tidak Setuju & 29 & 8,6 \\
5 & Sangat Tidak Setuju & 0 & o \\
\hline
\end{tabular}

Sumber : Data diolah

\section{Analisis Instrumen Penelitian}

\section{Uji Validitas}

Hasil uji validitas untuk variable keimanan, penghargaan, altruism, kepuasan diri, organisasi dan tingkat partisipasi berzakat dinyatakan valid yang ditentukan dengan membandingkan antara $r$ tabel dengan $r$ hitung dengan ketentuan jika nilai $r$ hitung lebih besar dari nilai $r$ tabel maka pernyataan tiap item pada variable tersebut dinyatakan valid dan layak digunakan untuk penelitian. Hasil uji validitas variable penelitian ini dapat dilihat pada tabel berikut

Tabel 8

Hasil Uji Validitas Variabel Penelitian

\begin{tabular}{ccccc}
\hline Variabel & Pernyataan & R hitung & R tabel & Keterangan \\
\hline Keimanan & Item 1 & 0,600 & 0,1807 & Valid
\end{tabular}

JISFIM: Journal of Islamic Social Finance Management, Volume 1, No 2 Tahun 2020 http://jurnal.iain-padangsidimpuan.ac.id/index.php/JISFIM 


\begin{tabular}{|c|c|c|c|c|}
\hline & Item 2 & 0,872 & & Valid \\
\hline & Item 3 & 0,830 & & Valid \\
\hline & Item 4 & 0,579 & & Valid \\
\hline \multirow[t]{4}{*}{ Penghargaan } & Item 1 & 0,676 & \multirow{4}{*}{0,187} & Valid \\
\hline & Item 2 & 0,586 & & Valid \\
\hline & Item 3 & 0,733 & & Valid \\
\hline & Item 4 & 0,700 & & Valid \\
\hline \multirow[t]{4}{*}{ Altruism } & Item 1 & 0,734 & \multirow{4}{*}{0,187} & Valid \\
\hline & Item 2 & 0,658 & & Valid \\
\hline & Item 3 & 0,718 & & Valid \\
\hline & Item 4 & 0,593 & & Valid \\
\hline \multirow[t]{4}{*}{ Kepuasan Diri } & Item 1 & 0,704 & \multirow{4}{*}{0,187} & Valid \\
\hline & Item 2 & 0,715 & & Valid \\
\hline & Item 3 & 0,767 & & Valid \\
\hline & Item 4 & 0,594 & & Valid \\
\hline \multirow[t]{4}{*}{ Organisasi } & Item 1 & 0,716 & \multirow{4}{*}{0,187} & Valid \\
\hline & Item 2 & 0,701 & & Valid \\
\hline & Item 3 & 0,752 & & Valid \\
\hline & Item 4 & 0,588 & & Valid \\
\hline Tingkat & Item 1 & 0,679 & \multirow{4}{*}{0,187} & Valid \\
\hline Partisipasi & Item 2 & 0,733 & & Valid \\
\hline \multirow[t]{2}{*}{ Berzakat } & Item 3 & 0,749 & & Valid \\
\hline & Item 4 & 0,560 & & Valid \\
\hline
\end{tabular}

Sumber : Data diolah

\section{Uji Reliabilitas}

Hasil uji reliabilitas untuk variable keimanan, penghargaan, altruism, kepuasan diri, organisasi dan tingkat partisipasi berzakat dinyatakan reliabel yang ditentukan dengan membandingkan hasil cronbach's alpha dengan ketentuan jika nilai cronbach's alpha lebih besar dari o,6 maka variable penelitian tersebut dinyatakan reliabel. Hasil uji reliabilitas variable penelitian ini dapat dilihat pada tabel berikut.

\section{Tabel 9}

\section{Hasil Uji Reliabilitas Variabel penelitian}

\begin{tabular}{llll}
\hline Variabel & Cronbach's Alpha & Syarat uji & Keterangan \\
\hline
\end{tabular}


242 I Determinan Tingkat Partisipasi Zakat Di Masa Pandemi Covid-19

$\begin{array}{cccc}\text { Keimanan } & 0,786 & >0,60 & \text { Reliabel } \\ \text { Penghargaan } & 0,766 & >0,60 & \text { Reliabel } \\ \text { Altruism } & 0,763 & >0,60 & \text { Reliabel } \\ \text { Kepuasan Diri } & 0,774 & >0,60 & \text { Reliabel } \\ \text { Organisasi } & 0,770 & >0,60 & \text { Reliabel } \\ \text { Tingkat Partisipasi } & 0,765 & >0,60 & \text { Reliabel } \\ \text { Berzakat } & & & \end{array}$

Sumber : Data diolah

\section{Uji Normalitas}

Uji normalitas bertujuan untuk menguji data penelitian baik variable dependen maupun variable independent terdistribusi normal atau tidak, karena penelitian yang baik adalah penelitian yang datanya normal. Uji normalitas penelitian ini menggunakan uji kolmogrovsmirnow dengan taraf signifikansi 5 persen. Uji normalitas variable penelitian ini dapat dilihat pada tabel berikut.

Tabel 10

Uji Normalitas Variabel Penelitian

\begin{tabular}{cccc}
\hline Variabel & Kolmogrov-Smirnow & Sig. & Keputusan \\
\hline Keimanan & 0,182 & 0,10 & Normal \\
Penghargaan & 0,125 & 0,10 & Normal \\
Altruism & 0,118 & 0,10 & Normal \\
Kepuasan Diri & 0,139 & 0,10 & Normal \\
Organisasi & 0,171 & 0,10 & Normal \\
Tingkat Partisipasi Berzakat & 0,159 & 0,10 & Normal
\end{tabular}

Sumber : Data diolah

\section{Uji Asumsi Klasik}

Hasil dari regresi berganda dapat digunakan sebagai alat prediksi yang baik dan tidak boleh terjadi kesalahan asumsi klasik dalam penelitiannya, penelitian yang baik adalah penelitian yang bebas dari kesalahan multikolinearitas, heteroskedastisitas dan autokorelasi. Hasil uji asumsi klasik dalam penelitian ini dapat dilihat pada tabel berikut.

\section{Tabel 11}

\section{Uji Asumsi Klasik Penelitian}

JISFIM: Journal of Islamic Social Finance Management, Volume 1, No 2 Tahun 2020 http://jurnal.iain-padangsidimpuan.ac.id/index.php/JISFIM 


\begin{tabular}{lccl}
\hline \multicolumn{1}{c}{ Asumsi Klasik } & $\begin{array}{c}\text { Uji yang } \\
\text { digunakan }\end{array}$ & Ketentuan & Keputusan \\
\hline Multikolinearitas & VIF & Bebas Multikolinearitas \\
- Keimanan & 1,038 & Bebas Multikolinearitas \\
- Penghargaan & 1,027 & $>10$ & Bebas Multikolinearitas \\
- Altruisme & 1,041 & Bebas Multikolinearitas \\
- Kepuasan Diri & 1,012 & Bebas Multikolinearitas \\
- Organisasi & 1,065 & & \\
Heteroskedastisitas & Spearman Rho & & Bebas Heteroskedastisitas \\
- Keimanan & 0,867 & & Bebas Heteroskedastisitas \\
- Penghargaan & 0,888 & & Bebas Heteroskedastisitas \\
- Altruisme & 0,854 & Bebas Heteroskedastisitas \\
- Kepuasan Diri & 0,757 & & Bebas Heteroskedastisitas \\
- Organisasi & 0,641 & & Bebas Autokorelasi \\
Autokorelasi & Durbin Watson & 1,883 & \\
\hline Sumber : Data & & &
\end{tabular}

Sumber : Data diolah

\section{Uji Hipotesis}

Uji hipotesis bertujuan untuk mengetahui seberapa jauh hipotesis penelitian dapat diterima berdasarkan data yang telah dikumpulkan. Uji hipotesis dilakukan bukan untuk menguji kebenaran hipotesis, akan tetapi dilakukan untuk menguji diterima atau ditolaknya hipotesis yang bersangkutan. Uji hipotesis terdiri dari uji parsial dalam bentuk uji t, uji simultan dalam bentuk uji f dan uji koefisien determinasi. Hasil uji hipotesis penelitian ini dapat dilihat pada tabel berikut.

Tabel 12

Uji Hipotesis Penelitian

\begin{tabular}{lccc}
\hline \multicolumn{1}{c}{ Uji Hipotesis } & $\begin{array}{c}\text { Uji yang } \\
\text { digunakan }\end{array}$ & Ketentuan & Keputusan \\
\hline Parsial & T hitung & \\
- Keimanan & $-2,082$ & & Berpengaruh \\
- Penghargaan & 0,867 & \multirow{1}{*}{, 66437} & Tidak berpengaruh \\
- Altruism & $-0,278$ & & Tidak berpengaruh
\end{tabular}

JISFIM: Journal of Islamic Social Finance Management, Volume 1, No 2 Tahun 2020 http://jurnal.iain-padangsidimpuan.ac.id/index.php/JISFIM 
- Kepuasan Diri

- Organisasi

Simultan

Berpengaruh

Tidak berpengaruh

F hitung

$$
\text { 2,106 }
$$

1,85

R-Square

0,119

Koefisien Determinasi

Sumber : Data diolah

\section{Pengaruh keimanan terhadap tingkat partisipasi berzakat di masa pandemic covid-19}

Berdasarkan hasil uji parsial, factor keimanan berpengaruh terhadap tingkat partisipasi berzakat di masa pandemic covid-19 di lingkungan IAIN Padangsidimpuan. Keimanan yang dimiliki oleh individu dapat menjadi motor penggerak seorang muslim untuk melaksanakan amal ma'ruf, salah satunya melalui zakat. Peran zakat mampu mengurangi jumlah dan persentase keluarga miskin, serta mengurangi kedalaman dan keparahan kemiskinan (Beik, 2009) dan dapat mengurangi ketimpangan pendapatan antara individu (Ayuniyyah dkk., 2018). Apalagi di masa pandemic covid ini, angka kemiskinan semakin meningkat, dengan adanya zakat diharapkan dapat membantu masyarakat miskin untuk bangkit dari keterpurukannya, dan individu yang ikut serta berpartisipasi dalam membayar zakat menandakan bahwa individu tersebut masih memiliki iman di dalam dirinya.

Pengaruh penghargaan terhadap tingkat partisipasi berzakat di masa pandemic covid-19

Berdasarkan hasil uji parsial yang dilakukan, ternyata factor penghargaan tidak berpengaruh terhadap tingkat partisipasi berzakat di masa pandemic covid ini. Karena apapun amal ma'ruf yang kita lakukan haruslah dengan keikhlasan, dan bukan untuk mendapatkan pujian dari orang lain yang kita kenal dengan sebutan riya. Dosen dan pegawai di lingkungan IAIN Padangsidimpuan berpartisipasi dalam berzakat bukan karena tujuan untuk mendapatkan penghargaan berupa pujian, hal ini sesuai dengan pengetahuan yang diperoleh tentang kewajiban untuk membayar zakat. (Nugroho \& Nurkhin, 2019) berdasarkan hasil penelitiannya mengatakan bahwa pengetahuan zakat berpengaruh terhadap minat muzakki membayar zakat profesi yang didukung oleh dorongan dari diri individu untuk mencari informasi tentang kewajiban berzakat.

\section{Pengaruh altruism terhadap tingkat partisipasi berzakat di masa pandemic covid-} 19

JISFIM: Journal of Islamic Social Finance Management, Volume 1, No 2 Tahun 2020 http://jurnal.iain-padangsidimpuan.ac.id/index.php/JISFIM 
Berdasarkan hasil uji parsial, factor altruism tidak berpengaruh terhadap tingkat partisipasi berzakat di masa pandemic covid di lingkungan IAIN Padangsidimpuan. Dosen dan pegawai di IAIN Padangsidimpuan mengeluarkan zakat bukan karena melihat kondisi atau keadaan masyarakat di masa pandemic saja akan tetapi tanpa adanya kondisi covid tetap mengeluarkan zakat karena sudah dianggap sebagai kewajiban dan meyakini bahwa di dalam harta yang dimiliki ada hak orang miskin yang membutuhkan.

\section{Pengaruh kepuasan diri terhadap tingkat partisipasi berzakat di masa pandemic covid-19}

Berdasarkan hasil uji parsial, factor kepuasan diri berpengaruh terhadap tingkat partisipasi berzakat di masa pandemic covid di lingkungan IAIN Padangsidimpuan. Kepuasan diri yang dimaksud disini bukan menunjukkan bangga diri atas sesuatu hal yang dilakukan, akan tetapi lebih kepada perasaan bahagia atau senang karena sudah melakukan hal baik yang diperintahkan Allah dan Rasulullah.

\section{Pengaruh organisasi terhadap tingkat partisipasi berzakat di masa pandemic covid-19}

Berdasarkan hasil uji parsial, factor organisasi tidak berpengaruh terhadap tingkat partisipsi berzakat di masa pandemic covid di lingkungan IAIN Padangsidimpuan, hal ini didukung karena partisipasi membayar zakat bukan karena tempat bekerja ada di institusi keagamaan akan tetapi karena kesadaran diri atas kewajiban membayar zakat, dan masih melakukan pembayaran zakat secara individu. Membayar zakat secara individu yang selama ini banyak dilakukan dikalangan masyarakat menyebabkan tidak terarahnya distribusi zakat, sehingga peran kelembagaan zakat berkurang dan bahkan tidak ada perannya di dalam suatu wilayah (Haki, 2020).

\section{KESIMPULAN}

Hasil pengujian yang dilakukan dapat disimpulkan bahwa factor keimanan dan kepuasan diri berpengaruh terhadap tingkat partisipasi berzakat di lingkungan IAIN Padangsidimpuan, sedangkan factor penghargaan, altruism dan organisasi tidak berpengaruh terhadap tingkat partisipasi berzakat di IAIN Padangsidimpuan. Hal ini menjelaskan bahwa dosen dan pegawai di IAIN Padangsidimpuan berpartisipasi dalam mengeluarkan zakat yang didasari atas pengetahuan keagamaan tentang keharusan dan kewajiban dalam mengeluarkan zakat atas penghasilan yang diperoleh.

\section{DAFTAR PUSTAKA}

JISFIM: Journal of Islamic Social Finance Management, Volume 1, No 2 Tahun 2020 http://jurnal.iain-padangsidimpuan.ac.id/index.php/JISFIM 
Al Jaffri Saad, R., \& Haniffa, R. (2014). Determinants of zakah (Islamic tax) compliance behavior. Journal of Islamic Accounting and Business Research, 5(2), 182-193. https://doi.org/10.1108/JIABR-10-2012-0068

Ayuniyyah, Q., Pramanik, A. H., Saad, N. Md., \& Ariffin, M. I. (2018). ZAKAT FOR POVERTY ALLEVIATION AND INCOME INEQUALITY REDUCTION. Journal of Islamic Monetary Economics and Finance, 4(1), 85-100. https://doi.org/10.21098/jimf.v4i1.767

Azzahra, F., \& Majid, M. S. A. (2020). What Drives Muzakki to Pay Zakat at Baitul Mal? Shirkah: Journal of Economics and Business, 5(1), 27. https://doi.org/10.22515/shirkah.v5i1.297

Beik, I. S. (2009). Analisis Peran Zakat dalam Mengurangi Kemiskinan: Studi Kasus Dompet Dhuafa Republika. Jurnal Pemikiran dan Gagasan, 2. https://www.researchgate.net/profile/Irfan_Beik/publication/281207037_Analisis_Per an_Zakat_dalam_Mengurangi_Kemiskinan_Studi_Kasus_Dompet_Dhuafa_Republika /links/55db325508aed6a199ac553e/Analisis-Peran-Zakat-dalam-MengurangiKemiskinan-Studi-Kasus-Dompet-Dhuafa-Republika.pdf?origin=publication_detail

Beik, I. S., \& Alhasanah, I. M. (2012). ANALISIS FAKTOR-FAKTOR YANG MEMPENGARUHI TINGKAT PARTISIPASI DAN PEMILIHAN TEMPAT BERZAKAT DAN BERINFAK. Universitas Islam Indonesia, 2(1), 64-75.

Cokrohadisumarto, W. bin M., Zaenudin, Z., Santoso, B., \& Sumiati, S. (2019). A study of Indonesian community's behaviour in paying zakat. Journal of Islamic Marketing, 11(4), 961-976. https://doi.org/10.1108/JIMA-10-2018-0208

Hadi, M. (2010). Problematika zakat profesi \& solusinya: Sebuah tinjauan sosiologi hukum Islam. Pustaka Pelajar.

Haki, U. (2020). Pengaruh Pengetahuan Zakat dan Citra Lembaga Terhadap Minat Muzakki dalam Membayar Zakat Fitrah. Syiar Iqtishadi : Journal of Islamic Economics, Finance and Banking, 4(1), 81-97. http://dx.doi.org/10.35448/jiec.v4i1.8182

Muhammad, S. A., \& Saad, R. A. J. (2016). Determinants of Trust on Zakat Institutions and its Dimensions on Intention to Pay Zakat: A Pilot Study. Penerbit Akademia Baru : Journal of Advanced Research in Business and Management Studies, 3(1), 40-46.

Nakhrawie, A. A. (2011). Sucikan Hati dan Bertambah Kaya bersama Zakat. Delta Prima Press. Noor, J. (2015). METODOLOGI PENELITIAN: SKRIPSI, TESIS, DISERTASI, DAN KARYA ILMIAH Edisi Pertama. Kencana.

JISFIM: Journal of Islamic Social Finance Management, Volume 1, No 2 Tahun 2020 http://jurnal.iain-padangsidimpuan.ac.id/index.php/JISFIM 
Nugroho, A. S., \& Nurkhin, A. (2019). Pengaruh Religiusitas, Pendapatan, Pengetahuan Zakat Terhadap Minat Membayar Zakat Profesi Melalui Baznas Dengan Faktor Usia sebagai Variabel Moderasi. Economic Education Analysis Journal, 8(3), 955-966. https://doi.org/10.15294/eeaj.v8i3.35723

Salwa, S., Shah, A., \& Hashim, H. (2018). The Factors Associated with Zakat Compliance Behaviour among Employees. IJEM: International Journal of Economics and Management, 12(S2), 687-696.

Setiawan, F., \& Hasanah, I. (2016). KEMISKINAN DAN PENGENTASANNYA DALAM PANDANGAN ISLAM. Dinar: Jurnal Ekonomi dan Keuangan Islam, 3(2), 1-11. https://doi.org/10.21107/dinar.v3i2.2698

Sugiyono. (2017). STATISTIKA UNTUK PENELITIAN. Alfabeta.

Trianto, B., Siregar, S., \& Nasution, M. Y. (2020). Does the Mustahik Demographic and SocioCultural Affect to the Successful of Poverty Alleviation? International Journal of Zakat, 5(1), 67-81. https://doi.org/10.37706/ijaz.v5i1.208

WASPADA. (2020, April 28). MASA PANDEMI, BI SUMUT PREDIKSI ANGKA KEMISKINAN NAIK. waspada.co.id. https://waspada.co.id/2020/o4/masa-pandemi-bi-sumutprediksi-angka-kemiskinan-naik/

JISFIM: Journal of Islamic Social Finance Management, Volume 1, No 2 Tahun 2020 http://jurnal.iain-padangsidimpuan.ac.id/index.php/JISFIM 